\title{
Early records of wasting-disease-like damage patterns in eelgrass Zostera marina
}

\author{
C. Den Hartog
}

Laboratory of Aquatic Ecology, Catholic University, Toernooiveld, 6525 ED Nijmegen, The Netherlands

ABSTRACT: A survey of herbarium material in the collections of the British Museum (Natural History), London, UK, and the Rijksherbarium, Leiden. The Netherlands, indicated that wasting-disease-like damage patterns occurred in eelgrass Zostera marina $\mathrm{L}$. of the British Isles and the Netherlands long before the epidemic of the $1930^{\prime}$ s caused the notorious decline of this species along the North-Atlantic coasts of Europe and North America. Herbarium records indicate little correlation with published records of earlier eelgrass declines. It is therefore suggested that wasting disease is an inconspicuous, but widespread endemic phenomenon, normally occurring in eelgrass beds.

In the years between 1930 and 1940 Zostera marina was struck by an epidemic, generally referred to as wasting disease, along both the American and the European coasts of the Atlantic Ocean. As a result, populations of Z. marina declined dramatically and in various regions the species became totally extinct. Why this disease reached epidemic proportions in such a large area, and so suddenly, has not been satisfactorily explained (Den Hartog 1987). Recently, attention was again focused on the wasting disease, as a recurrence of it and subsequent decline of $Z$. marina was reported by Short et al. $(1986,1987)$ from the north-eastern coast of the USA.

The symptoms of wasting disease are easily recognized (Short et al. 1988) (Fig. 1). In the leaves, lesions appear which cause some air lacunae to fill with water (Fig. 1C). Small brown spots and streaks then develop, generally spreading longitudinally and becoming darker. After a few weeks these may cover the whole blade at which point the leaves become detached. After repeated defoliation, rhizomes become discoloured and die.

Butcher (1934) referred to the fact that as diseased leaves and those dying at the end of the season from other causes are very much alike in appearance, it is impossible to decide whether the cause of death is normal or otherwise'. Similar remarks were made by
Rasmussen $(1973,1977)$. However, the most characteristic phenomenon of the disaease is that the youngest leaves exhibit spots and streaks, thus making the disease identifiable. It has been established that the damage pattern of the disease is caused by a slimemold-like organism, preliminarily identified as Labyrinthula sp. 'P' (Muehlstein et al. 1988).

One of the questions raised in the 1930's was whether earlier declines of Zostera marina were known. Cottam $(1934,1935)$ provided evidence that there had been various declines along the coast of the USA, although wasting disease was not referred to as the cause. Butcher (1934) noted that, in England, several beds of $Z$. marina declined gradually from 1920 , while in 1931-1932 the decline was more abrupt, 'but in most cases there seems to be very little in common as regards both physicochemical and biological factors which could account for its disappearance'. Later Martin (1954) listed a number of declines of $Z$. marina from the USA and Europe. All declines recorded prior to the 1930 's had a local character, i.e., there were no, or insufficient, indications that they were widespread, and none occurred simultaneously on both sides of the Atlantic. Further, in none of these was reference made to the occurrence of wasting disease.

As far as is known, no research has been carried out to check, in herbaria, whether damage patterns as caused by wasting disease have been found before 1930, and whether these can provide evidence for earlier epidemics.

Materials and methods. A survey was made of all herbarium material of Zostera marina from Great Britain and Ireland in the British Museum (Natural History), London, and of all material of this species kept in the Rijksherbarium, Leiden. All together this material consisted of a thousand sheets, often with more than one specimen per sheet. In most cases, careful visual inspection of the material appeared sufficient to detect 


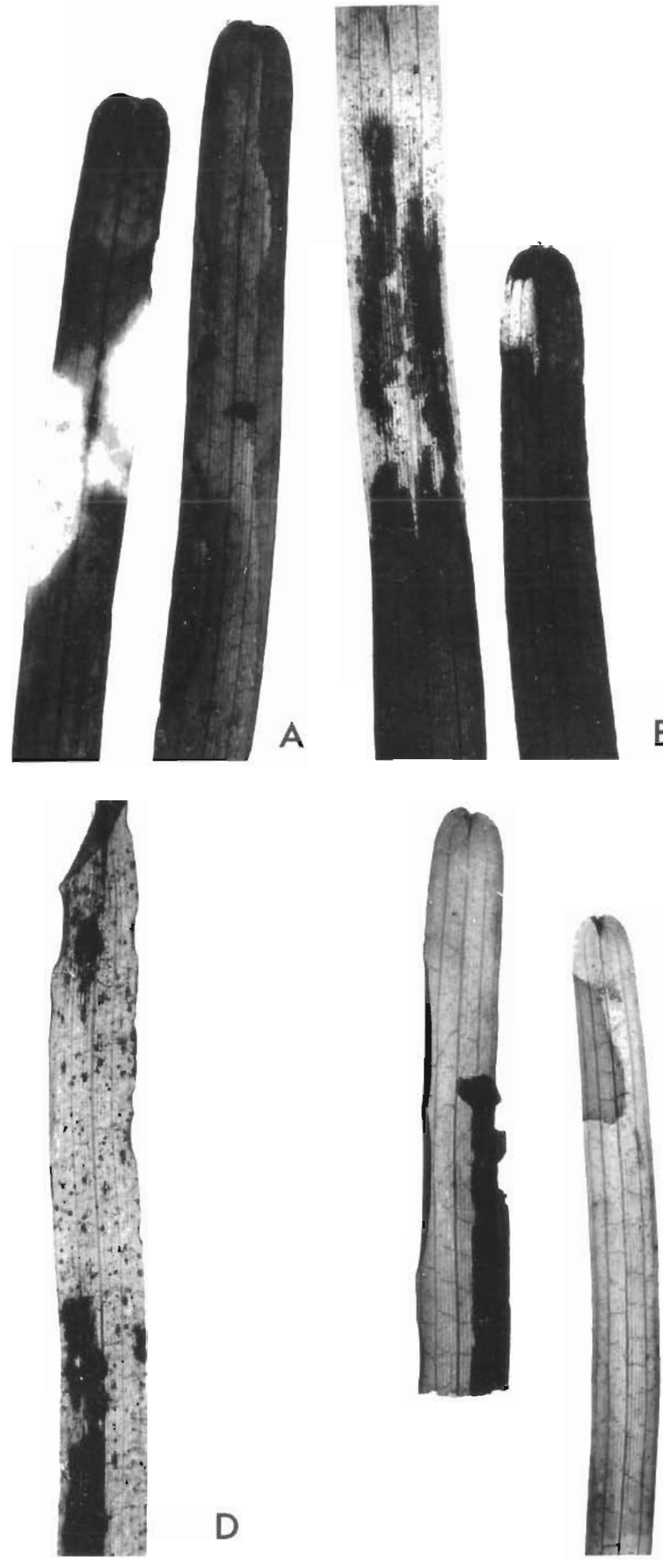

Fig. 1. Zostera marina. Leafblades with wasting-diseaselike damage patterns from the Netherlands. (A) Noordpolderzijl, August 1856; (B) Wissekerke, July 1877 , heavily diseased old leaves: (C) Wissekerke, July 1877, the tip of a youngest leaf, showing the initial stage of the disease, i.e., the filling of the air lacunae with water; (D) E Terschelling, June 1918; (E) - Terschelling, August 1939 
the damage patterns. However, particularly in the case of old, brown material, it was necessary to use translucent light to enable the detection of such patterns. Only specimens with considerable damage were listed as 'diseased'; specimens with an occasional spot were not considered

Results. In Table 1 all material in which wastingdisease-like damage patterns were observed, prior to 1930 , is listed. The number of diseased specimens appears to be very small in comparison to the total number of specimens investigated. The oldest diseased specimen from Britain dates back to ca 1840 (Curnow 1844), and from the Netherlands to 1856. There appears to be no obvious pattern in the distribution of diseased specimens in the British Isles and the Netherlands. In the British Isles, collections were made from June to September, and in the Netherlands in June, July and August, thus well within the normal growth season of Zostera marina.

The years when collections were made, with the exception of 2 records $(1915,1917$, see Table 1), were not identical with years in which Zostera marina exhibited a decline (Martin 1954), i.e., 1854, 1889, 1894, $1908,1913,1915,1917,1920-1922$.

Discussion. When studying herbarium material one has to keep in mind that mounted specimens are generally not randomly taken. Usually one chooses, particularly where herbs and small plants are concerned, the finest and most complete specimens fitting the size of a herbarium sheet. Specimens with senescent foliage or with disease phenomena are usually rejected, as other specimens are available, and if such specimens are used the decomposing parts may even be removed. Further, and this is particularly true for aquatic plants, collectors often do not take sufficient care to mount the specimens adequately, e.g. by carefully spreading the leaves; often the dried material is not suitable for study, without time consuming preparation procedures. A second limitation with respect to the use of herbarium material, is that usually, the only purpose of the material is for documentation. Thus the recognition of the wasting-disease-like damage patterns in herbarium specimens of Zostera marina is of limited value in reconstructing possible former epidemics. At most the data can be used as additional evidence, if it is clear from other sources that in the year of collection a decline of $Z$. marina occurred. As an example, it should be noted that in the decade 1930 to 1940 when wasting disease destroyed Zostera beds, and much research on this subject was carried out, very few diseased specimens were entered in the herbarium collections studied (Table 2).

The presented documentation of wasting-diseaselike damage patterns in Zostera marina over a long period, prior to the outbreak of the disastrous epidemic in the 1930's, suggests that wasting disease is an incon-
Table 1 Zostera marina. Wasting-disease-like damage patterns collected prior to 1930, showing location and date of collection, and collector Codes for herbaria where the material is kept are indicated in parentheses. BM: British Museum; L: Leiden

\begin{tabular}{|c|c|}
\hline Country & Locality details \\
\hline The Netherlands & $\begin{array}{l}\text {-Groningen, Noordpolderzijl, near } \\
\text { Usquert, } 15 \text { Aug 1856, G. E. } \\
\text { Stratingh (L) (Fig. 1A) } \\
\text { - Friesland, Schiermonnikoog, } 31 \\
\text { Aug 1926, D. Koopmans-Forstmann } \\
\text { \& A. N. Koopmans (L) } \\
\text { - Terschelling, 13-14 Jun 1918, } \\
\text { C. G. G. J. van Steenis (L) (Fig. 1D) } \\
\text { - Zuid Holland, Beach near Katwijk, } \\
\text { in Herb. Jansen \& Wachter 790/792, } \\
\text { undated, but certainly long before } \\
\text { 1930 (L) } \\
\text { - Goeree-Overflakkee, near Nieuwe } \\
\text { Tonge, 10 Aug 1917, R. Breur \& A. } \\
\text { W. Kloos Jr (L) } \\
\text {-Zeeland, Schouwen-Duiveland, } \\
\text { Burgsluis, } 28 \text { Aug 1929, G. Kruse- } \\
\text { man (L) - Noord Beveland, Wissekerke, on } \\
\text { submerged mudflats, Jul 1877, D. } \\
\text { Lako (L) (Fig. 1B, C) } \\
\text { - Walcheren, Veere, Aug 1863, A. } \\
\text { Walraven (L) }\end{array}$ \\
\hline Scotland & $\begin{array}{l}\text { - Tayside, Montrose Basin, Sep } 1915 \text {, } \\
\text { R. \& M. Corstophine } 1723 b \text { (BM) } \\
\text { - Highland, Westerness, Loch na } \\
\text { Nuagh near Loch Ailort, Jul } 1902 \text {, } \\
\text { Miss M. E. Ashby (BM) } \\
\text { - Strathclyde, Cantire, shore of Loch } \\
\text { Sween near Kilmichael of Inverlus- } \\
\text { sa, } 6 \text { Aug } 1899, \text { C. E. Salmon (BM) } \\
\text { - Shore at Inverkip (Renfrewshire), } \\
\text { Jum, no year given, but certainly be- } \\
\text { fore 1930, William Gourlie } 1135 \\
\text { (BM) }\end{array}$ \\
\hline England & $\begin{array}{l}\text { - Humberside, (N. Lincolnshire), } \\
\text { Cleethorpes, Sep 1885, H. Searle } \\
\text { (BM) } \\
\text { - Dorset, Lyme Regis, } 26 \text { Aug 1881, F. } \\
\text { J. Hanbury (BM) } \\
\text { - Cornwall, Marazion, without date, } \\
\text { but certainly collected around } 1840 \text {, } \\
\text { W. Curnow (BM) } \\
\text { - Scilly Islands, Tresco, } 3 \text { Sep } 1869 \text {, } \\
\text { M. A. Lawson (BM) }\end{array}$ \\
\hline Wales & $\begin{array}{l}\text { - Pembrokeshire, shore of a creek on } \\
\text { Milford Haven, near Pwllcrochan, } \\
\text { Jul 1885, J. W White (BM) }\end{array}$ \\
\hline
\end{tabular}

spicuous but widespread endemic phenomenon normally occurring in eelgrass beds. However, when an eelgrass population comes under environmental stress by natural and/or anthropogenous causes, this may lead to weakening of the host and create the right circum- 
Table 2. Zostera marina. Wasting-disease-like damage patterns collected between 1930 and 1940, showing location and date of collection, and collector. Codes for the herbaria where the material is kept are indicated in parentheses. BM: British Museum; L: Leiden

\begin{tabular}{|c|c|}
\hline Country & Locality details \\
\hline The Netherlands & $\begin{array}{l}\text { - Friesland, Terschelling, Stryper } \\
\text { kwelder (salt marsh area) near dis- } \\
\text { charge sluice, } 28 \text { Aug 1939, collector } \\
\text { not known (L) (Fig. 1E) }\end{array}$ \\
\hline Scotland & $\begin{array}{l}\text {-Outer Hebrides, North Uist, Lingay } \\
\text { strand, } 10 \text { Jun 1936, M. S. Campbell } \\
\text { (BM) } \\
\text { - Boreray, } 20 \text { Jun 1938, J. W. Camp- } \\
\text { bell (BM) } \\
\text { - Fife, Firth of Tay, south side, shore } \\
\text { between Tay Bay and Tentsmuir } \\
\text { Point, } 17 \text { Sep 1938, J. Berry (BM) }\end{array}$ \\
\hline England & $\begin{array}{l}\text { - Essex, Westmersey, } 10 \text { Sep } 1932, \\
\text { Th. J. Foggitt } 1614 \text { (BN) } \\
\text { - Hampshire, Pennington marshes, } \\
\text { Lymington, } 12 \text { Sep 1934, collector } \\
\text { not known (BM) } \\
\text { - Dorset, The Fleet, Jun 1934, T G. } \\
\text { Tutin (BM) }\end{array}$ \\
\hline Ireland & $\begin{array}{l}\text { - Lough Ine, } 7 \text { Apr 1934, T M. Harris, } \\
\text { very narrow-leaved and wide- } \\
\text { leaved specimens (BM) }\end{array}$ \\
\hline
\end{tabular}

stances for the parasitic organism to multiply and to expand; in extreme situations this may lead to an epidemic (Short et al. 1988). This Iine of thought may help explain the local outbreaks of wasting disease, but not the triggering of the 1930's epidemic which struck eelgrass in the whole North Atlantic. However, evidence that environmental circumstances in various parts of the North Atlantic were very different at that time is building up, and that possibly, there was no single cause for this notorious epidemic (Den Hartog 1987). In Danish waters, Rasmussen $(1973,1977)$ convincingly showed that the decline in $Z$. marina in the $1930^{\prime}$ 's coincided with several years characterized by elevated summer water temperatures (up to $3^{\circ} \mathrm{C}$ higher than 'normal') and mild winters. In the Dutch Wadden Sea, however, the decline of $Z$. marina could not be linked with temperature (Den Hartog 1987, Giesen et al. 1990 a), but there appeared to be a clear correlation with sunshine deficits during consecutive growing seasons in combination with an increase in turbidity and a profound change in the tidal pattern due to hydrotechnical works (Giesen et al. 1990a, b). In both cases Z. marina was placed under a continuous stress over an extended period; this may have weakened the plants thus rendering them susceptible to disease, and giving Labyrinthula the change to develop a large-scale epidemic. Research, under controlled conditions, of this hostparasite relation is now in progress.

\section{LITERATURE CITED}

Butcher, R. W. (1934). Zostera. Report on the present condition of eelgrass on the coasts of England based on a survey during August to October, 1933. J. Cons. perm. int. Explor. Mer 9: 49-65

Cottam, C. (1934). Past periods of eelgrass scarcity. Rhodora 36: $261-264$

Cottam, C. (1935). Further notes on past periods of eelgrass scarcity. Rhodora 37: 269-271

Curnow, W. (1844). Rarer plants of Penzance. Phytologist 1: $1142-1144$

Den Hartog, C. (1987). Wasting disease and other dynamic phenomena in Zostera beds. Aquat. Bot. 27: 3-14

Giesen, W B. J. T., van Katwijk, M. M., Den Hartog, C. (1990a). Temperature, salinity, insolation and wasting disease of eelgrass (Zostera marina L.) in the Dutch Wadden Sea in the 1930's. Neth. J. Sea Res. (in press)

Giesen, W. B. J. T., van Katwijk, M. M., Den Hartog, C. (1990b). Eelgrass condition and turbidity in the Dutch Wadden Sea. Aquat. Bot. (in press)

Martin, A. C. (1954). A clue to the eelgrass mystery. Trans. 19th N. Am. Wildi. Conf. Washington, DC, p. 441-449

Muehlstein, L. K., Porter, D., Short, F. T (1988). Labyrinthula sp., a marine slime mold producing the symptoms of wasting disease in eelgrass, Zostera marina. Mar. Biol. 99: $465-472$

Rasmussen, E. (1973). Systematics and ecology of the Isefjord marine fauna (Denmark). Ophelia 11: 1-495

Rasmussen, E. (1977). The wasting disease of eelgrass (Zostera marina) and its effects on environmental factors and fauna. In: McRoy, C. P., Helfferich. C. (eds.) Seagrass ecosystems, a scientific perspective. M. Dekker, New York p. 1-51

Short, F. T., Ibelings, B. W., Den Hartog, C. (1988). Comparison of a current eelgrass disease to the wasting disease in the 1930's. Aquat. Bot. 30: 295-304

Short, F. T., Mathieson, A. C., Nelson, J. I. (1986). Recurrence of an eelgrass wasting disease on the border of New Hampshire and Maine. Mar Ecol. Prog. Ser. 29: 89-92

Short, F. T., Muehlstein, L. K., Porter, D. (1987). Eelgrass wasting disease: cause and recurrence of a marine epidemic. Biol. Bull. mar biol. Lab., Woods Hole 173: $557-562$

Manuscript first received: July 18, 1989

Revised version accepted: October 3, 1989 